\title{
Study of Clearness Index of Atmosphere over Eastern City of Nepal, Biratnagar
}

Prakash M. Shrestha, Usha Joshi, Narayan P. Chapagain, Indra B. Karki, and Khem N. Poudyal

Journal of Nepal Physical Society

Volume 7, No 3, 2021

(Special Issue: ANPA Conference, 2021)

ISSN: 2392-473X (Print), 2738-9537 (Online)

\section{Editors:}

Dr. Nabin Malakar (Editor in chief)

Worcester State University

Dr. Pashupati Dhakal

Thomas Jefferson National Accelerator Facility, USA

Dr. Arjun Dahal

University of South Alabama, USA

Dr. Chiranjivi Lamsal

SUNY Platsburgh, USA

Dr. Dilli Raj Paudyal

University of Regina, Canada

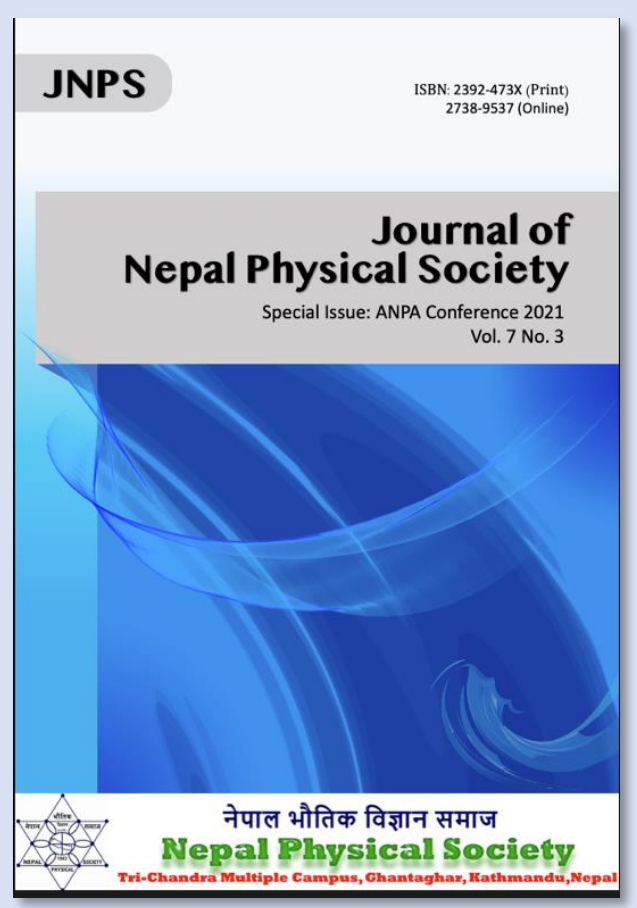

Managing Editor:

Dr. Binod Adhikari

St. Xavier's College, Kathmandu, Nepal

JNPS, 7 (3), 6-13 (2021)

DOI: http://doi.org/10.3126/jnphyssoc.v7i3.42703

Published by: Nepal Physical Society

P.O. Box: 2934

Tri-Chandra Campus

Kathmandu, Nepal

Email: npseditor@gmail.com 


\title{
Study of Clearness Index of Atmosphere over Eastern City of Nepal, Biratnagar
}

\author{
Prakash M. Shrestha ${ }^{1,2^{*}}$, Usha Joshi ${ }^{1,2}$, Narayan P. Chapagain ${ }^{3}$, \\ Indra B. Karki ${ }^{1,4}$, Khem N. Poudyal ${ }^{5}$ \\ ${ }^{I}$ Department of Physics, Patan Multiple Campus, IoST, T. U. \\ ${ }^{2}$ Central Department of Physics, IoST, T.U. \\ ${ }^{3}$ Department of Physics, Amrit Campus, IoST, T.U. \\ ${ }^{4}$ Nepal Open University \\ ${ }^{5}$ Department of Physics, Pulchowk Engineering Campus, IoE, T. U. \\ *e-mail: prakash.shrestha@pmc.tu.edu.np
}

\begin{abstract}
Solar radiation data are of great significance for energy harvesting. This paper's main objective is to study clearness index of atmosphere over Biratnagar (latitude: $26.45^{\circ} \mathrm{N}$, longitude: $87.27^{\circ} \mathrm{E}$, altitude: $72 \mathrm{~m}$ a. s. 1.), an eastern city of Nepal. Daily global solar radiation data are derived by using CMP6 pyranometer for one year period (2015). The monthly, annual and seasonal variations of global solar radiation, clearness index and visibility were analyzed. The annual average of global solar radiation (GSR), clearness index $\left(\mathrm{K}_{\mathrm{T}}\right)$ and visibility indices are found to be $11.37 \pm 3.76 \mathrm{MJ} / \mathrm{m}^{2} / \mathrm{day}, 0.37 \pm 0.15$ and $7.06 \pm 5.56 \mathrm{~km}$ are respectively. In the study period, number of clear days $\left(\mathrm{K}_{\mathrm{T}}>0.65\right)$ and number of cloudy days $\left(\mathrm{K}_{\mathrm{T}}<0.34\right)$ are found to be 26 and 172 respectively. Study of clearness index of atmosphere and its dependence on meteorological parameters (such as maximum temperature, minimum temperature, rainfall, relative humidity, total ozone column and dew point) are used on agriculture, hydrology, and climate change. Finding of GSR and visibility helps for energy harvesting and aviation.
\end{abstract}

\section{Received: Aug 30, 2021 Revised: Dec 23, 2021 Accepted: Dec 31, 2021}

Keywords Global solar radiation, clear and cloudy day, clearness index, meteorological parameter, visibility

\section{INTRODUCTION}

The Sun radiates $4 \times 10^{26} \mathrm{~J}$ energy per second in the form of an electromagnetic wave of wavelength $300 \mathrm{~nm}$ to $3000 \mathrm{~nm}[1]$. The average solar radiation $1367 \mathrm{~W} / \mathrm{m}^{2}$ (solar constant, $\mathrm{I}_{\mathrm{sc}}$ ) [2] incidents on the outer layer of the atmosphere when Earth is at mean distance $1.49 \times 10^{8} \mathrm{~km}$ from the Sun. As the orbit of the Earth around the Sun is elliptical with eccentricity $(\varepsilon)$, the solar energy incident on a specific point of outer layer of the atmosphere at a specific time $\left(H_{o}\right)$ is inversely proportional to the square of distance between the Sun and the Earth. It depends on solar sunshine angle $\left(\omega_{s}\right)$, solar declination $(\delta)$ latitude $(\phi)$ and day numbers of year (DOY, $n_{d}$ ) [3]. The solar radiation passing through the atmosphere is scattered and absorbed by molecules, water droplets, dust and aerosol. According to the Beer Lambert's law, solar radiation $\left(H_{o}\right)$ is attenuated exponentially in the atmosphere with extinction coefficient $(k)$ and optical air mass $(m)[4]$. The solar radiation that reaches to the ground is given by

$$
\begin{aligned}
& H_{g}=H_{o} e^{-k m} \\
& \text { where, } H_{o}=\frac{24}{\pi} I_{s c} \varepsilon\left(\omega_{s} \sin \delta \sin \phi+\right. \\
& \left.\qquad \cos \delta \cos \phi \sin \omega_{s}\right)
\end{aligned}
$$

Sun is the nearest star to us. Solar energy is free energy and a harmless source of energy. Study of clearness index of atmospheric turbidity and its effect of different meteorological parameters are used in agriculture, hydrology, climate change and 
energy harvesting. The solar radiation depends on physical parameters (attitude, longitude, altitude, optical air mass, aerosol, scattering, cloud, absorption, ozone and albedo) and meteorological parameters (such as precipitation, ambient temperature, wind speed, humidity, local weather conditions and seasonal variation) [5]. The solar energy on ground is due to direct and diffused radiation. The sum of the direct solar radiation and the diffused solar radiation is global solar radiation (GSR) [6].

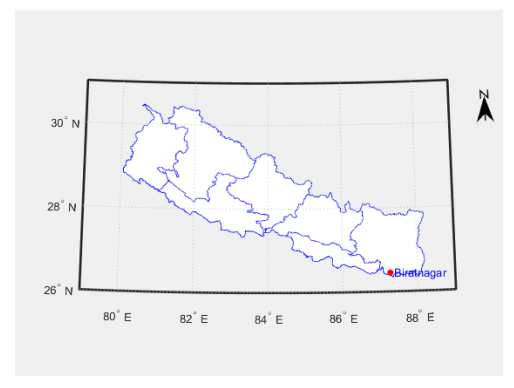

Figure.1: Map of Biratnagar [source: Survey Department,2020]

Nepal is a landlocked South Asian mountainous country with a large beautiful landscape situated between latitudes of $26.36^{\circ} \mathrm{N}$ to $30.45^{\circ} \mathrm{N}$ and longitudes of $80.06^{\circ} \mathrm{E}$ to $88.2^{\circ} \mathrm{E}$. The elevation of the country ranges from $60 \mathrm{~m}$ to $8848 \mathrm{~m}$ within a span of $200 \mathrm{~km}$ from south to north and about 800 $\mathrm{km}$ from east to west [7]. The population growth rate of Nepal is about $1.34 \%$ [8]. In the fiscal year $2018 / 19,587 \times 10^{12} \mathrm{~J}$ energy was consumed. Out of that energy, conventional, commercial and renewable energy consumption were $68.5 \%, 29.4$ $\%$ and $2.1 \%$ respectively [9] which shows significant need for energy harvesting. Nepal is situated between two giant industrial countries India and China and their industrial byproduct can directly impact on atmosphere over Nepal. Therefore, a detailed study of the clearness index of atmospheric parameters is very important. Nepal lies in the sunbelt (latitude $15^{\circ} \mathrm{N}$ to $35^{\circ} \mathrm{N}$ ). The annual average solar energy measuring 4.95 , 5.44, 5.19 and $4.61 \mathrm{kWh} / \mathrm{m}^{2} /$ day are found in Biratnagar, Pokhara, Kathmandu and Lukla respectively in 26th January, 2010[1]. The annual average global solar radiation and clearness index are $16.68 \pm 4.60 \mathrm{MJ} / \mathrm{m}^{2} /$ day and $0.51 \pm 0.12$ respectively on Kathmandu Valley for 2012 [10]. The annual average solar insolation and clearness index $5.11 \pm 2.34 \mathrm{kWh} / \mathrm{m}^{2} /$ day and $0.71 \pm 0.12$ on Jumla for 2012[11]. In comparison, annual average Global solar radiation for New Delhi is 18.25 $\mathrm{MJ} / \mathrm{m}^{2} /$ day for 1986 - 2000[12]. The annual average of Global solar radiation for 1995 to 2010 in Beijing and in Lhasa are $13.5 \mathrm{MJ} / \mathrm{m}^{2} /$ day and $20.4 \mathrm{MJ} / \mathrm{m}^{2} /$ day respectively [13].

Biratnagar (latitude: $26.45^{\circ} \mathrm{N}$, longitude: $87.27^{\circ} \mathrm{E}$, altitude: $72 \mathrm{~m}$ a. s. 1.) is the eastern metropolitan city of Nepal, the capital of Province number 1. It covers 77 square $\mathrm{km}$ area shown in figure 1 . Population and population density of Biratnagar are respectively are 2,42,548 and 3,100 per square $\mathrm{km}$ [14]. It lies in the subtropics climate zone. The average annual the maximum temperature is $30.2^{\circ}$ $\mathrm{C}$ and the minimum temperature is $19.0^{\circ} \mathrm{C}$ with average precipitation is $1,891.8 \mathrm{~mm}$. Using satellite data, the average annual mean solar insolation and clearness index for 1983 to 2005 was $32.4 \mathrm{MJ} / \mathrm{m}^{2} /$ day and 0.58 respectively [15].

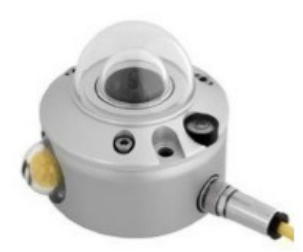

Figure.2: CMP6 pyranometer [source: www.kippzonen.com]

\section{MATERIALS AND METHODS}

The solar radiation is attenuated exponentially in the atmosphere with extinction coefficient $(k)$ and optical air mass $(m)$. Clearness index $\left(K_{T}\right)$ is ratio of $H_{g}$ to $H_{o}$ and extinction coefficient is due to ozone, water vapor, gas mixture, aerosol and Rayleigh scattering. Optical air mass $(m)$ depends on atmospheric pressure $(P)$, solar zenith angle $\left(\theta_{z}\right)$, solar hour angle $(\omega)$, latitude $(\phi)[16]$.

$$
m=\frac{P}{101325} \frac{1}{\left(\cos \theta_{z}+0.15\left(93.885-\theta_{z}\right)^{-1.253}\right)}
$$

where

$$
\theta_{z}=\cos ^{-1}(\sin \delta \sin \phi+\cos \delta \cos \phi \cos \omega)
$$

For a cloudy day, $K_{T}$ is less than 0.34 while for a clear day, $K_{T}$ is greater than 0.65 [17].

Visibility of atmosphere in $\mathrm{km}$ [18] is given by

$$
R=\frac{3.921}{k}
$$




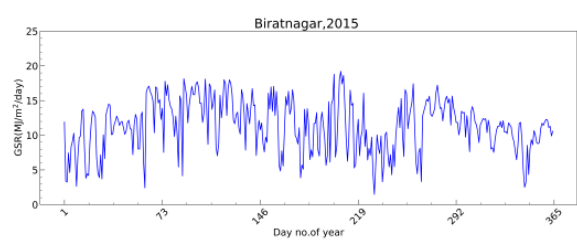

a) $G S R$

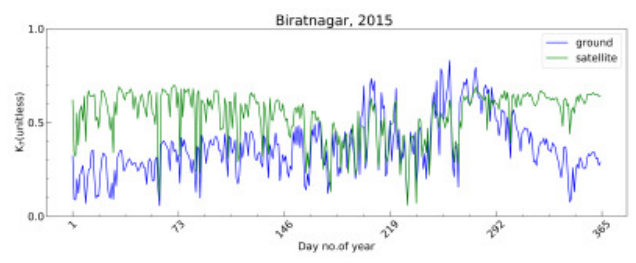

b) Clearness index

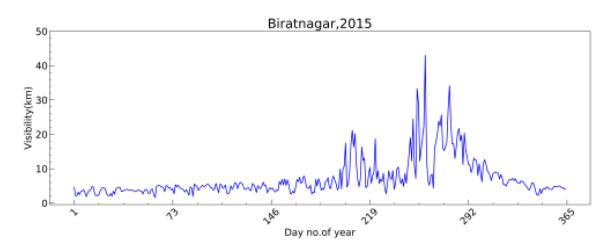

c) Visibility

Figure.3: Daily variation of solar parameters

Daily GSR and meteorological data are collected from the Department of Hydrology and Meteorology (DHM), government of Nepal for the year 2015. GSR is measured by CMP6 first class pyranometer in $\mathrm{W} / \mathrm{m}^{2}$ shown in Figure 2.CMP6 pyranometer has thermopile sensor with spectral range $285 \mathrm{~nm}$ to $2800 \mathrm{~nm}$ [19]. Data of Total ozone content (TOC) are collected from NASA website.

Open-source software Python 3.7 is used to analyze data and plot graphs. Mean, standard deviation $(\sigma)$ and correlation coefficient(r) and standard error (SE) is used as statistical parameters to analyze and describe graphs. Data are presented in form of mean \pm standard deviation.

$$
\begin{aligned}
& \sigma=\sqrt{\frac{1}{n} \sum_{i=1}^{n}\left(x_{i}-\bar{x}\right)^{2}} \\
& S E=\frac{\sigma}{\sqrt{n}} . \\
& r=\frac{\sum_{i=1}^{n}\left(x_{i}-\bar{x}\right)\left(y_{i}-\bar{y}\right)}{\sqrt{\sum_{i=1}^{n}\left(x_{i}-\bar{x}\right)^{2}} \sqrt{\sum_{i=1}^{n}\left(y_{i}-\bar{y}\right)^{2}}}
\end{aligned}
$$

Here $\mathrm{n}$ is number of data. Correlation coefficient is used to find relation between two data. Its values lie between -1 to 1 .
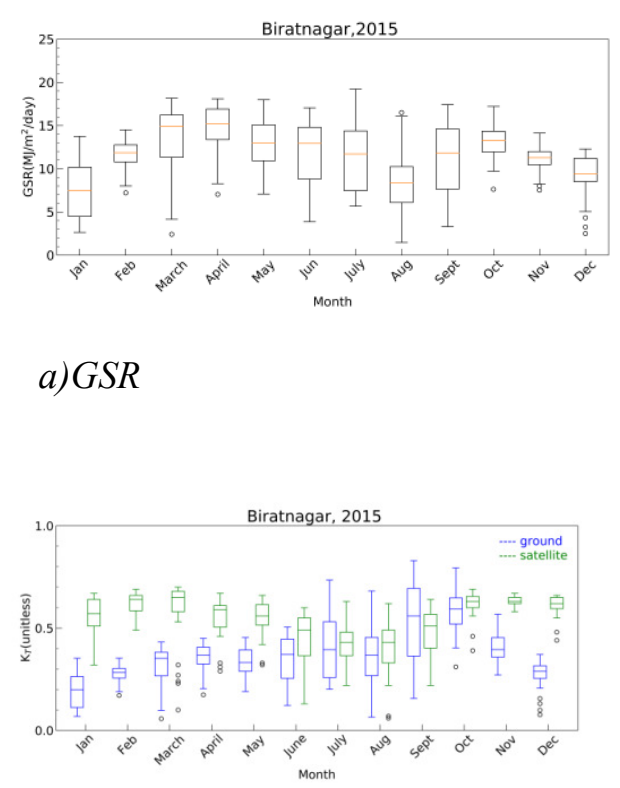

b) Clearness index

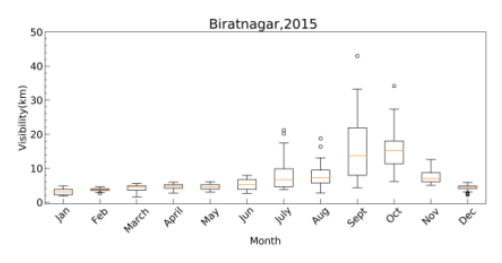

c) Visibility

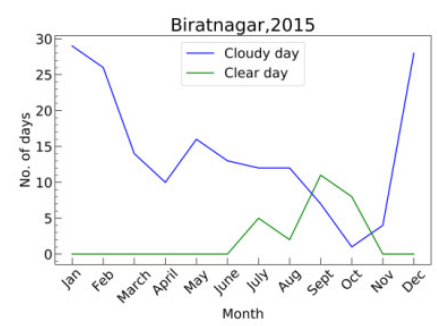

d)Frequency distribution of cloudy and clear days

Figure.4: Monthly variation of solar parameters 


\section{RESULTS AND DISCUSSION}

Figure 3(a) indicates the daily variation of global solar radiation. GSR is a maximum 19.22 $\mathrm{MJ} / \mathrm{m}^{2} /$ day on July 26 and minimum 1.47 $\mathrm{MJ} / \mathrm{m}^{2} /$ day on August 20. The annual mean of global solar radiation (GSR) is $11.37 \pm 3.76$ $\mathrm{MJ} / \mathrm{m}^{2} /$ day. Figure $3(\mathrm{~b})$ indicates the daily variation of clearness index $\left(K_{T}\right)$. According to ground-based data, clearness index is a maximum of 0.82 on September 18 and a minimum of 0.05 on March 2 due to local weather while from satellite-based data, the maximum value of 0.7 on September 27 and the minimum of 0.06 on August 19. Deviation of ground- based and satellite-

based data is due to reflection of solar radiation by cloud and absorption by atmosphere. Annual mean of clearness index $\left(\mathrm{K}_{\mathrm{T}}\right)$ for ground-based data and satellite-based data are $0.37 \pm 0.15$ and $0.53 \pm 0.13$ respectively. Number of clear days $\left(\mathrm{K}_{\mathrm{T}}>0.65\right)$ is 26 and that of cloudy days $\left(\mathrm{K}_{\mathrm{T}}\right.$ $<0.34)$ is 172 . Figure $3(\mathrm{c})$ indicates a daily variation of visibility. Visibility is a maximum of $43 \mathrm{~km}$ on September 18 and a minimum of 2 $\mathrm{km}$ on March 2.

Figure 4(a) shows the monthly variation of global solar radiation. GSR is a maximum of $13.91 \pm 3.93 \mathrm{MJ} / \mathrm{m}^{2} /$ day in April and a minimum of $7.51 \pm 3.64 \mathrm{MJ} / \mathrm{m}^{2} /$ day in January. Variation is significant high in March whereas less variation is in November. Figure 4(b) shows monthly variation of clearness index. According to ground -based data, clearness index is maximum $0.56 \pm 0.14$ in September whereas minimum $0.19 \pm 0.09$ in January. However, according to satellite data, the clearness index is maximum $0.63 \pm 0.02$ in November whereas minimum $0.41 \pm 0.11$ in June. Figure 4(c) shows a monthly variation of visibility. Visibility is a maximum of $15 \pm 10 \mathrm{~km}$ in September and a minimum of $3 \pm 1 \mathrm{~km}$ in January. Large variation of visibility in September whereas less variation in February. The annual mean of visibility is $7 \pm 5 \mathrm{~km}$. Figure 4(d) show the monthly variation of frequency distribution of cloudy and clear days. There are no clear days in January to May and November to December. There is seen to be 11 clear days on August, 29 cloudy days on January and one day in September.

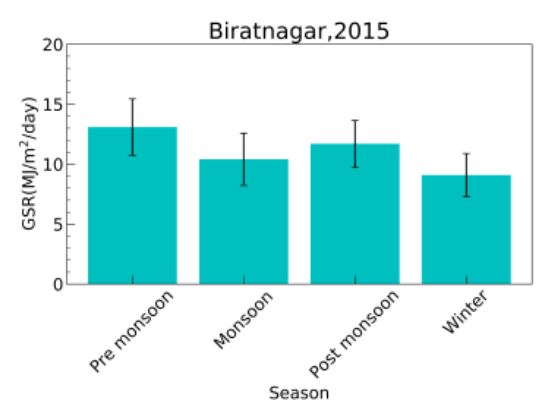

a) GSR

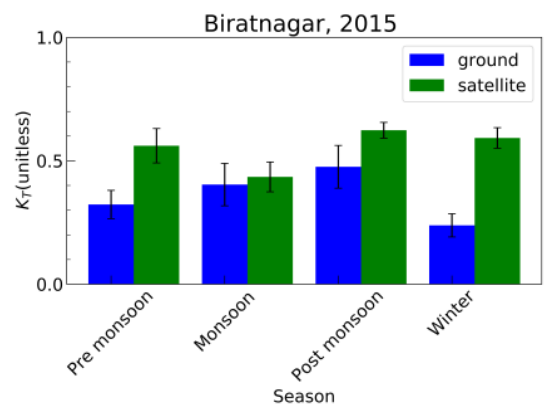

b) Clearness index

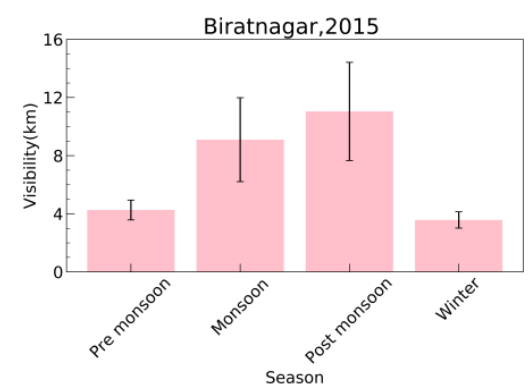

c) Visibility

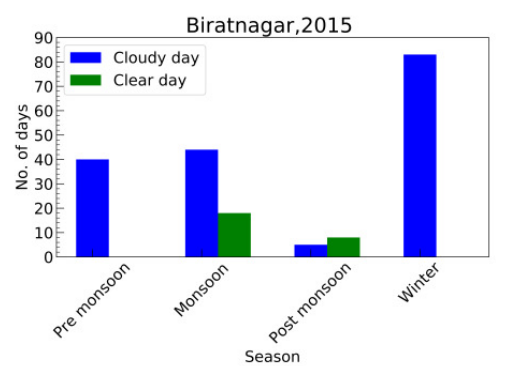

d) Frequency distribution of cloudy and clear days

Figure.5: Seasonal variation of solar parameters 
Figure 5(a) shows seasonal variation of GSR.GSR is maximum $13.09 \pm 4.09 \mathrm{MJ} / \mathrm{m}^{2} /$ day in pre monsoon (March, April, May) whereas minimum $9.09 \pm 3.12 \mathrm{MJ} / \mathrm{m}^{2} /$ day in winter (December, January, February). Figure5(b) shows seasonal variation of clearness index. According to ground -based data, clearness index is a maximum of $0.47 \pm 0.12$ in post monsoon (October, November) whereas a minimum of $0.23 \pm 0.08$ in winter. According to satellite- based data, clearness index is a maximum of $0.62 \pm 0.04$ in post monsoon (October, November) whereas a minimum of 0.43 \pm 0.12 in monsoon (June, July, August, September).

Figure 5(c) shows seasonal variation of visibility. Visibility is maximum $11 \pm 5 \mathrm{~km}$ in post monsoon whereas minimum value is $4 \pm 1 \mathrm{~km}$ in winter. Figure 5(d) shows seasonal variation of frequency distribution of cloudy and clear days. There is no clear day in pre monsoon and winter. It seems that 18 days are clear in monsoon, 83 days are cloudy in winter and 5 days are cloudy in post monsoon.

Figure 6 is a histogram of the clearness index. First quartile, second quartile (median) and third quartile are $0.27,0.35$ and 0.44 respectively. Skewness is 0.62 . The distribution of clearness index is positively tailed. Kurtosis is. 0.26 . The distribution is leptokurtic. Data are fitted in normal distribution with mean $(\mu) 0.37$ and standard deviation $(\sigma) 0.15$. Then $\chi^{2}$ test is done.

$$
\begin{aligned}
& f(x)=\frac{1}{\sqrt{2 \pi} \sigma} e^{-\frac{1}{2}\left(\frac{x-\mu}{\sigma}\right)^{2}} \\
& \chi^{2}=\sum_{i=1}^{n}\left(\frac{E_{i}-O_{i}}{E_{i}}\right)^{2}
\end{aligned}
$$

Where $\mathrm{O}_{\mathrm{i}}$ and $\mathrm{E}_{\mathrm{i}}$ are observed and expected values respectively. The calculated value of $\chi^{2}$ is 40.03 whereas the table value of $\chi^{2}$ at $95 \%$ confident label at 8 degree of freedom is 2.733 . As the calculated value is large, the distribution is not normal (symmetric).

Figure 7(a) shows trend analysis of clearness index with day numbers of year. In this analysis, data are fitted in straight line $(y=m x+c)$. Trend line is

$$
K_{T}=0.27+0.00054 \mathrm{n}_{d}
$$

Slope $(\mathrm{m})$ is positive, that mean clearness index slightly increases with day. Figure 7(b) shows a seasonal variation of clearness index. Fourier series is used to analysis seasonal variation

$$
K_{T s}=a_{0}+a_{1} \cos \left(\frac{360}{365} n_{d}\right)+b_{1} \sin \left(\frac{360}{365} n_{d}\right)
$$

Offset $\left(a_{0}\right)$ is 0.37 . Fourier coefficients, $a_{1}$ and $b_{1}$ are -0.05 and -0.10 respectively. Seasonal amplitude $\left(\sqrt{a_{1}^{2}+b_{1}^{2}}\right)$ is 0.11 . Figure 7 (c) shows a cyclic variation of clearness index. For cyclic variation, 7 days moving average is taken. Average of clearness index increases from first day of year to 290 day of year and then it decreases. Figure 7(d) shows autocorrelation of clearness index with day. Autocorrelation coefficient (ac) is given by

$$
a c=\frac{\sum_{i=1}^{n-t}\left(x_{i}-\bar{x}\right)\left(x_{i+t}-\bar{x}\right)}{\sqrt{\sum_{i=1}^{n-t}\left(x_{i}-\bar{x}\right)^{2}} \sqrt{\sum_{i=1}^{n-t}\left(x_{i+t}-\bar{x}\right)^{2}}}
$$

Autocorrelation coefficient is used to determine correlation of clearness index of $i^{\text {th }}$ and $(i+t)^{\text {th }}$ day of year. From $t=50$ to $t=300$-day, autocorrelation is negative.

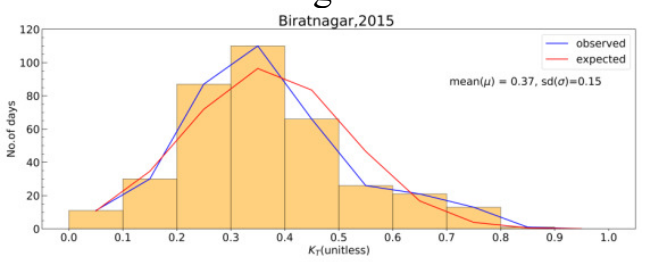

Figure.6: Histogram of clearness index

Figure 8(a) shows a variation of clearness index with maximum temperature. The correlation coefficient is 0.61 . The annual average of maximum temperature is $30 \pm 4^{\circ} \mathrm{C}$. Figure $8(\mathrm{~b})$ shows a variation of clearness index with minimum temperature. The correlation coefficient is 0.36 . The annual average of minimum temperature is $20 \pm 6^{\circ} \mathrm{C}$. Figure 8(c) shows the variation of clearness index with rainfall. The correlation coefficient is -0.10 whereas number of rainy days is 84 and annual rain fall is $940 \mathrm{~mm}$. Figure 8(d) shows a variation of clearness index with relative humidity $(\mathrm{RH})$. The correlation coefficient is -0.24 . Figure $8(\mathrm{e})$ shows a variation of clearness index with water content $(w)$. The correlation coefficient is 0.36 . Figure $8(\mathrm{f})$ shows variation of clearness index with dew point.

The correlation coefficient is 0.37 . Figure $8(\mathrm{~g})$ shows a variation of clearness index with total ozone content (TOC).

The correlation coefficient is 0.50 . The annual average of TOC is $265 \pm 17$ DU. Figure $8(\mathrm{~h})$ shows a variation of clearness index with relative sun shine hour $(r s s h=n / N)$. Here $n$ and $\mathrm{N}$ are sun shine 
hour and day length respectively. The correlation coefficient is 0.53 . There is positive correlation of clearness index with maximum temperature, total zone column and relative sun shine hour. No significant effect of minimum temperature, water content, dew point, rain fall and relative humidity on clearness index.

\section{CONCLUSIONS}

During the study period of the year 2015, about $243 \times 10^{3}$ MWh solar energy reaches on Biratnagar in a day which is about $37 \%$ of the solar energy that incidents on the upper surface of atmosphere above Biratnagar. That solar energy can be harvested into electric energy for industry as well as agriculture purpose. Due to fog, industry and high population density, visibility is less than $5 \mathrm{~km}$ in January. It is not good visibility for aviation and transportation.

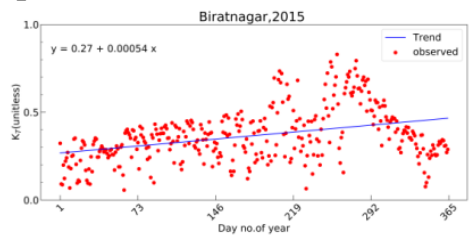

a) Trend analysis

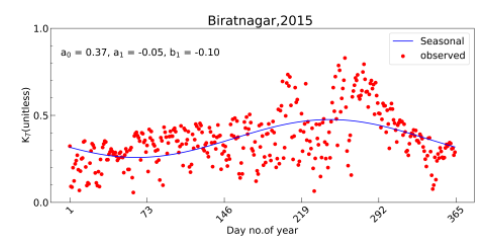

b) Seasonal variation

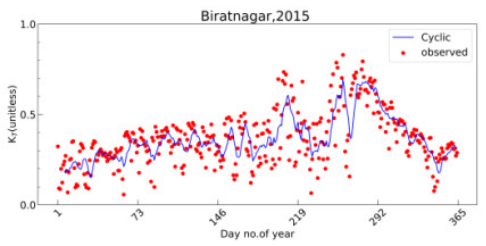

c) Cyclic variation

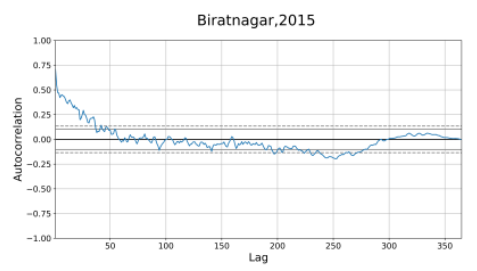

d) Autocorrelation

Figure.7: Time series analysis of clearness index

\section{AUTHOR CONTRIBUTIONS}

Methodology, original draft preparation, visualization, writing and review are done by first author (PhD Scholar). Editing is done by second authors (PhD Scholars). Review is done by other authors (supervisors) supervise. All authors have read and agreed to the published version of the manuscript.

It is assured that the paper has been checked by all the co-authors.

\section{ACKNOWLEDGMENT}

Authors are grateful to faculty members of Central Department of Physics, Department of Physics of Patan Multiple Campus, Institute of Science and Technology (IoST) for opportunity for research. We are also grateful to Department of Hydrology and Meteorology (DHM) and NASA for providing data and Nepal Academy of Science and Technology (NAST) for providing $\mathrm{PhD}$ fellowship.

\section{EDITOR'S NOTE}

This manuscript was submitted to the Association of Nepali Physicists in America (ANPA) Conference 2021 for publication in the special issue of Journal of Nepal Physical Society. 


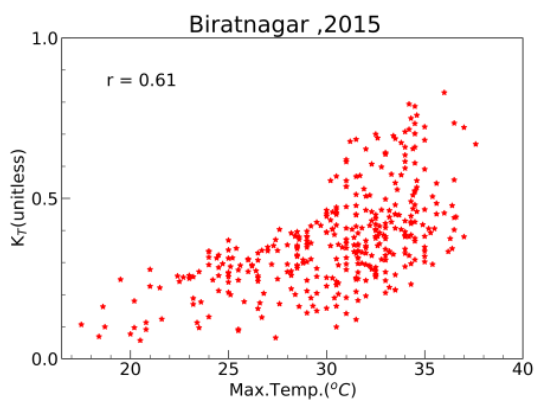

a) Maximum temperature

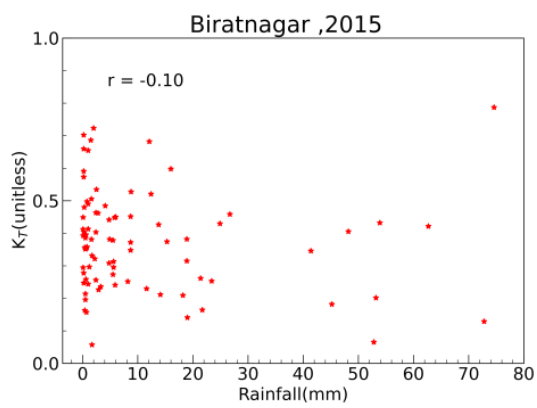

c)Rainfall

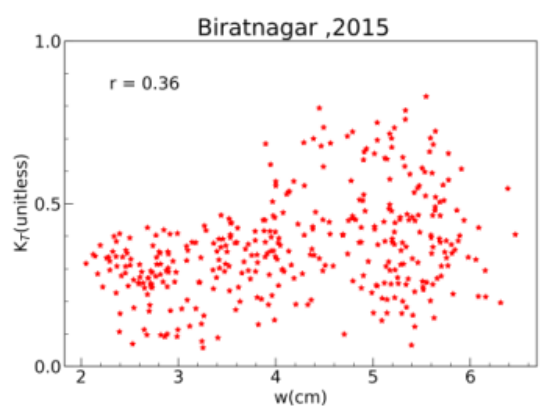

e) Water content

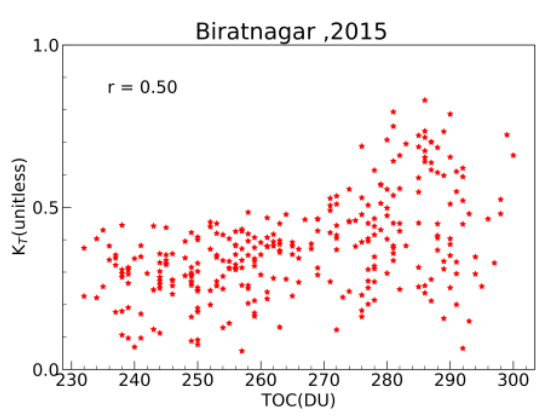

g) Total ozone column(TOC)

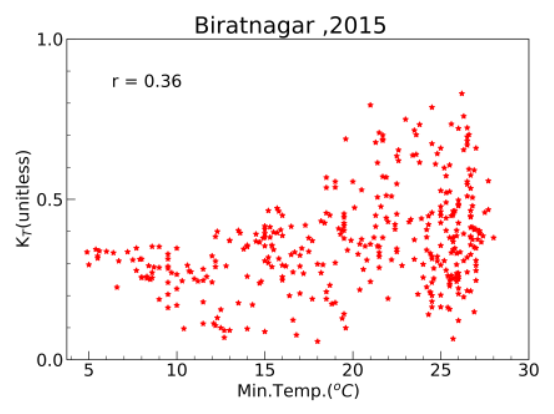

b) Minimum temperature

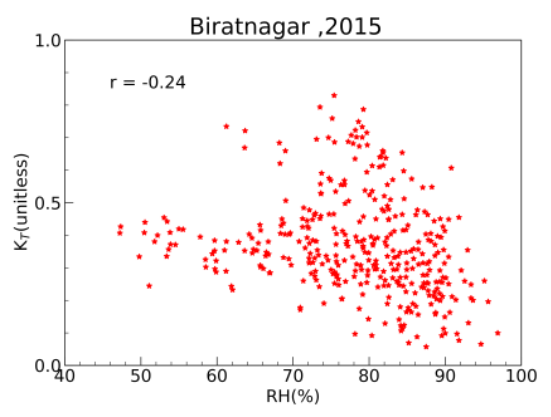

d) Relative humidity

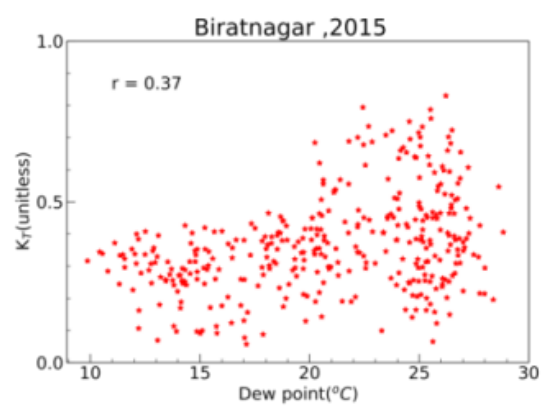

f) Dew point

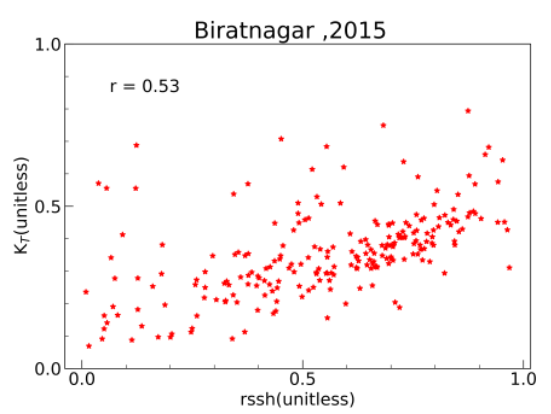

h) Relative sun shine hour (rssh)

Figure.8 (a-h): Variation of clearness index with meteorological parameters 


\section{REFERENCES}

[1] Poudyal KN, Bhattarai BK, Sapkota BK, and at lowland region Biratnagar using satellite data. Kjeldstad B. Solar radiation potential at four sites of BIBECHANA,2021, 18(1):193-200. Nepal. Journal of the Institute of Engineering, 2011, 0.3126/bibechana.v18i1.29689.

8(3):189-197, DOI: 10.3126/jie.v8i3.5944.

[16] Wang L, Chen Y, Niu Y, Salazar GA, and Gong W. [2] Duffie JA and Weckman WA. Solar engineering of Analysis of atmospheric turbidity in clear skies at thermal processes. John Wiley \& Sons, 2013. ISBN 978- Wuhan, central China. Journal of Earth Science, 1-118-67160-3. 2017,28(4):729-738. DOI: 10.1007/s12583-017-07562.

[3] Iqbal M. An introduction to solar radiation. New York: Academic Press, 1983. ISBN: 0-12-373752-4.

[17] Kudish AI, Wolf D, and Machlav Y. Solar radiation data for Beer Sheva, Israel. Solar Energy,

[4] Wallace JM and Hobbs PV. Atmospheric science: an 1983,30(1):33-37. DOI: 10.1016/0038-092X(83)90003introductory survey, volume 92, Elsevier,2006. ISBN: 0- 8. 12-732951-X.

[18] Horvath H. On the applicability of the koschmieder [5] Salby ML. Physics of the Atmosphere and Climate. visibility formula. Atmospheric Environment,1971, 5 Cambridge University Press, 2012. ISBN: 978-0-512- (3):177-184. DOI: 10.1016/0004-6981(71)90081-3. 76718-7.

[19] Instruction Manual CMP6 Pyranometer. Kipp and [6] Liou KN. An introduction to atmospheric radiation, Zonen, 2008, URL www.kippzonen.com. volume 84. Elsevier, 2002. ISBN: 0-12-451451-0.

[7] Majupuria R K and Majupuria T C. Nepal nature's paradise: insight into diverse facets of topography, flora and ecology. M Devi,Gwalior, India, 1999. ISBN: 9748614-94- 8 .

[8] CBS. Environment Statistics of Nepal. Central Bureau of Statistics, National Planning Commission Secretariat, Government of Nepal, 2012.

[9] Economic Survey 2018/019. Ministry of Finance, Government of Nepal, 2018.

[10] Shrestha PM, Chapagain NP, Karki IB, and Poudyal KN. Variation on atmospheric transmittance of solar radiation at Kathmandu valley. Journal of Nepal Physical Society,2020,6(1):105-112.DOI: 10.3126/jnphyssoc.v6i1.30558.

[11] Shrestha PM, Karki IB, Chapagain NP, and Poudyal KN. Study of linke turbidity factor on solar radiation over Jumla. Molung Educational Frontier, 2019,9:141-149. URL https://www.nepjol.info/index. $\mathrm{php/mef/article/view/34081/26830}$.

[12] Solar Radiation Handbook. Typical climatic data for selected radiation stations. A joint Project of Solar Energy Centre, MNRE Indian Metrological Department, 2008.

[13] Zhang Q, Cui N, Feng Y, Jia Y, Li Z, and Gong D.Comparative analysis of global solar radiation models in different regions of china. Advances in meteorology, 2018, 2018. DOI: 10.1155/2018/3894831.

[14] National Population and Housing Census 2011. Central Bureau of Statistics, National Planning Commission Secretariat,Government of Nepal, 2011. 